\title{
Understanding of effects of potassium on cardiac tissue by medical students: a critical appraisal
}

\author{
Raj Kumar Arya ${ }^{1}$, Parag Sharma ${ }^{2}$, Dinesh Kumar Jain ${ }^{1} *$
}

${ }^{1}$ Department of Pharmacology, G.R. Medical College, Gwalior 474001, Madhya Pradesh, India, ${ }^{2}$ Department of Pharmacology, L. N. Medical College, Bhopal 462037, Madhya Pradesh, India

Received: 1 November 2013 Accepted: 13 November 2013

*Correspondence to: Dr. Dinesh Kumar Jain, Email: dineshgrmc@gmail.com

(C) 2014 Arya RK et al. This is an open-access article distributed under the terms of the Creative Commons Attribution Non-Commercial License, which permits unrestricted non-commercial use, distribution, and reproduction in any medium, provided the original work is properly cited.

\begin{abstract}
Potassium $\left(\mathrm{K}^{+}\right)$is one of the most important ion present in the human body and involved in numerous physiological activities. It mainly affects heart and skeletal muscle but the effects are not confined to theses organs only. The article precisely focuses on the explaining the physiological as well as pathological aspects of potassium on cardiac tissue. This article tends to explain: The cause of difference in extra cellular and Intra cellular concentration of potassium when potassium channels are open in resting conditions, why are Purkinje fibers and ectopic tissue are more sensitive to effect of potassium, mechanisms responsible for increased action potential duration by hypokalemia and decreased action potential duration by hyperkalemia. Hypokalemia generates ectopic activities and hyperkalemia inhibits them, therapeutic effects of potassium administration without causing hyperkalemia. These issues will be discussed and try to be explained with the help of Ohm's law, Nernst equation and Nernst potential to sort out the complicated actions of potassium on cardiac tissue in a simplified manner. The primary aim of article is to improve understanding of potassium physiology by medical graduates, secondarily, convey message regarding improvement in teaching methodology in Pharmacology for the benefit of new generations.
\end{abstract}

Keywords: Hypokalemia, Hyperkalemia, Nernst equation, Membrane resting potential

\section{INTRODUCTION}

Pharmacology is a very difficult medical subject to learn and retain. Other medical subjects have visual and practical support to understand and learning while this facility is lacking in pharmacology e.g. Anatomy takes help from dissection, Pathology can be retained with the help of observation of gross specimens and histological studies. All clinical subjects are learned easily because patients are the main available visual support for study. In Pharmacology, conditions are totally different. Contents of pharmacology are not interrelated and there is overlapping also, which makes the subject very difficult to learn and retain. Hence teachers and students both face problems during study of pharmacology. Therefore it is also the duty of teachers to motivate students to use their reasoning ability to solve problems of retaining the subject and find a true solution for it. It is rightly written by an author, "If I did not really understand the problem, I could not find a true solution to it. Search for truth meant accumulating an understanding that would let one reason from observations to root cause". ${ }^{1}$ That's why it is our duty to teach medical students in such a way that they develop analytical approach of study rather cramming. This article tends to analyze effects of hypokalemia and hyperkalemia on cardiac tissues in a simplified manner to make it very easy to understand.

\section{EFFECTS OF HYPERKALEMIA AND HYPOKALEMIA AS MENTIONED IN TEXT BOOKS}

Actual observed effects of hyperkalemia include reduced action potential duration, slowed conduction, decreased pacemaker rate, and decreased pacemaker arrhythmogenesis. Conversely, the actual observed 
effects of hypokalemia include prolonged action potential duration, increased pacemaker rate, and increased pacemaker arrhythmogenesis. Furthermore, pacemaker rate and arrhythmias involving ectopic pacemaker cells appear to be more sensitive to change in serum potassium, compared with cells of sinoatrial node. ${ }^{2}$

Extra cellular potassium concentration and inward rectifier channel function are the major factors determining the membrane potential of the resting cardiac cells. For the pacemaker cells, the effect on permeability to potassium is important. "Hypokalemia increases the risk of early and delayed after-depolarization (DAD) and ectopic pacemaker activity. Correction of hypokalemia can restore sinus rhythm without the use of antiarrhythmic drug". 3

"The basic cardiac effects of potassium administration without causing hyperkalemia, are (1) Reduction in conduction velocity (2) prolongation of the refractory period and diminution of automaticity and are most marked in the Purkinje fibres". 4

\section{PROBLEMS TO UNDERSTAND}

At the undergraduate level it is difficult to understand basic mechanisms responsible for cardiac effects observed due to hypokalemia and hyperkalemia. Second problem to understand is regarding difference in intracellular and extra-cellular concentration of potassium, when $\mathrm{K}^{+}$channels are open in resting conditions. Intracellular concentration of $\mathrm{K}^{+}$is 142 $\mathrm{mEq} / \mathrm{L}$ while extra cellular concentration of $\mathrm{K}^{+}$is 4.2 $\mathrm{mEq} / \mathrm{L} . \mathrm{K}^{+}$should move from intracellular compartment to extra cellular compartment till concentration becomes equal, but difference in concentration gradient is maintained in resting potential.

One unique action of $\mathrm{K}^{+}$is that $\mathrm{K}^{+}$administration without causing hyperkalemia alters conduction velocity and refractory period, which is also difficult to explain. There are other questions also which needs to be addressed. Why are Purkinje fibers more sensitive to effect of $\mathrm{K}^{+}$than other cardiac tissues? Why is there increased concentration of $\mathrm{K}^{+}$inside the cells? What are the mechanisms responsible for increased action potential duration by hypokalemia and decreased action potential duration of hyperkalemia? Why are ectopic pacemaker cells more sensitive to change in serum potassium than cells of SA node?

\section{BASIC CONCEPTS}

Life was created in water which contained mainly potassium in beginning. That's why potassium is the main ion present inside the cell. Sodium was increased gradually in sea water due to rains and flow of water from earth to sea. Potassium has many physiological functions within cells including cellular metabolism, growth, glycogen and protein synthesis. "Potassium is the most abundant cation in the body with estimated total body stores of 3000 to $4000 \mathrm{mEq}$ ". 5 "The normal serum concentration range for potassium is 3.5 to $5 \mathrm{mEq} / \mathrm{L}$, whereas the intracellular potassium concentration is usually about $140 \mathrm{mEq} / \mathrm{L}$ ". ${ }^{6}$ "Ninety-eight percent of this amount is contained within the intracellular compartment, and the remaining $2 \%$ is distributed within the extra cellular compartment. The $\mathrm{Na}^{+}-\mathrm{K}^{+}$-ATPase pump located in the cell membrane is responsible for compartmentalization of potassium. This pump is an active transport system that maintains increased intracellular stores of potassium by transporting sodium out of the cell and potassium in to the cell at a ratio of $3: 2$. Consequently the pump maintains a higher concentration of potassium inside the cell". 7

A membrane potential arises when there is a difference in the electrical charge on the two side of the membrane, and which is due to difference in concentration of positive and negative ions. Active electrogenic pumping and passive ion diffusion both are also responsible for charge difference. "Electrogenic pumps also generate most of the electric potential across the plasma membrane in plants and fungi. In typical animal cells, however, passive ion movements make the largest contribution to the electric potential across the plasma membrane". ${ }^{9}$ The following discussion will certainly help to clear concept of development of potential. "Suppose that initially there is no voltage gradient across the plasma membrane (membrane potential is zero), but the concentration of $\mathrm{K}^{+}$ is high inside the cell and low outside. $\mathrm{K}^{+}$will tend to leave the cell through the $\mathrm{K}^{+}$leak channels, driven by its concentration gradient. As $\mathrm{K}^{+}$moves out, it will leave behind unbalanced negative charge, thereby creating an electric field or membrane potential, which will tend to oppose the further efflux of $\mathrm{K}^{+}$. The net efflux of $\mathrm{K}^{+}$will halt when the membrane potential reaches a value where this electrical driving force on $\mathrm{K}^{+}$exactly balances the effect of its concentration gradient i.e. when the electrochemical gradient for $\mathrm{K}^{+}$is zero. The equilibrium condition, in which there is no net flow of ions across the plasma membrane, defines the resting membrane potential for this idealized cell". 9 "The potential level across the membrane that exactly opposes net diffusion of a particular ion through the membrane is called the Nernst potential for that ion. The magnitude of this Nernst potential is determined by the ratio of the concentration of that specific ion on the two sides of the membrane. The greater this ratio, the greater the tendency for the ion to diffuse in one direction, and therefore the greater the Nernst potential required to prevent the diffusion." ${ }^{10}$ The following is the Nernst equation, can be used to calculate the Nernst potential for any univalent ion.

$$
\text { Electro Motive Force }=\text { EMF (millivolts })= \pm 61 \log \frac{\text { Conc. inside }}{\text { Conc. outside }}
$$


In this formula, it is usually assumed that the potential in the extra cellular fluid outside the membrane remains at zero potential and the potential inside the membrane is the Nernst potential. If the ion under consideration is a

$$
\text { Nernst for potential } \mathrm{K}^{+} \text {ion }=\mathrm{EMF}(\text { millivolts })=-61 \log \frac{\operatorname{Conc.inside}\left(\mathrm{K}^{+}\right)}{\operatorname{Conc.outeside}\left(\mathrm{K}^{+}\right)}=-61 \log \frac{142 \frac{\mathrm{mEq}}{\mathrm{L}}}{4 \frac{\mathrm{mEq}}{\mathrm{L}}}=-61 \log 35=[\log 35=1.54]=-61 \times 1.54=-94 \mathrm{mV}
$$

During resting condition of cell, an important subset of $\mathrm{K}^{+}$channels are open and are hence sometimes called $\mathrm{K}^{+}$ leaky channels, play an important part in maintaining the resting membrane potential. Very minute diffusion of $\mathrm{Na}^{+}$ions through $\mathrm{Na}^{+}$leaks channels, inside the cell, slightly alters MRP from - $94 \mathrm{mV}$ to $-90 \mathrm{mV}$ in resting conditions.

During phase 0 of action potential, $\mathrm{Na}^{+}$channels open and $\mathrm{Na}^{+}$ions enter inside the cell and intracellular negativity shifts from $-90 \mathrm{mV}$ to $+20 \mathrm{mV}$. At this intracellular positively of $+20 \mathrm{mV}$, there is not sufficient electric attraction for $\mathrm{K}^{+}$ion to prevent their efflux. Now concentration gradient of $\mathrm{K}^{+}$dominates and $\mathrm{K}^{+}$ions go negative ion then sign of potential is positive, and sign of potential is negative, if the ion under consideration is a positive ion.

$$
\mathrm{K}_{\mathrm{EMF}}=-61 \log \frac{\mathrm{K} \text { inside concentration }}{\mathrm{K} \text { outside concentration }}=-61 \log \frac{142 \mathrm{mEq} / \mathrm{L}}{8 \mathrm{mEq} / \mathrm{L}}=-61 \log 17=-75 \mathrm{mV}
$$

$\log 17=1.25$

In hyperkalemia of $8 \mathrm{mEq} / \mathrm{L}$ concentration, MRP is - 75 $\mathrm{mV}$. But slight leakage of $\mathrm{Na}^{+}$from extra cellular site in to intracellular site during resting conditions will alter MRP in hyperkalemia from $-75 \mathrm{mV}$ to $-70 \mathrm{mV} . \mathrm{Na}^{+}$ions are 100 time less permeable than $\mathrm{K}^{+}$ions during resting condition of cell. For neutralizing concentration gradient of $\mathrm{K}^{+}$, Nernst potential should be $-90 \mathrm{mV}$. When Nernst potential is comparatively less then concentration gradient will dominate and $\mathrm{K}^{+}$will come outside the cell. Speed of $\mathrm{K}^{+}$efflux will be increased. It means conductivity of $\mathrm{K}^{+}$migration from inside to outside the cell is increased. In this way $\mathrm{K}^{+}$conductance is increased. It may also be explained with the help of Ohm's law.

\section{Current flow $=$ Voltage difference/resistance $($ Ohm's law $)$ $=$ Voltage difference $\mathrm{x}$ conductivity}

According to this law, if voltage difference is reduced then conductivity is increased. In hyperkalemia, voltage difference across the resting membrane is reduced that's why conductivity of $\mathrm{K}^{+}$ions is increased in comparison to normal potassium concentration.

During phase 0 of action potential, in depolarization, $\mathrm{Na}^{+}$ ions enter the cell and change intracellular negativity from negative voltage to positive voltage. But in hyperkalemia, increased $\mathrm{K}^{+}$conductance causes efflux of $\mathrm{K}^{+}$during $\mathrm{O}$ phase which antagonizes voltage difference development due to $\mathrm{Na}^{+}$entry. It slows speed of the development of voltage difference due to $\mathrm{Na}^{+}$influx. Therefore conduction velocity is decreased in hyperkalemia. outside the cell, it is the beginning of repolarization with the opening of additional subset of $\mathrm{K}^{+}$channels during phase 1,2, 3 of action potential.

\section{EFFECTS OF HYPERKALEMIA ON CARDIAC TISSUES}

Hyperkalemia is defined when plasma potassium concentration rises more than $5 \mathrm{mEq} / \mathrm{L}$. If extra cellular concentration of potassium is $8 \mathrm{mEq} / \mathrm{L}$ then resting potential (MRP) will be
Following $\mathrm{K}^{+}$conductance, as $\mathrm{K}^{+}$efflux is increased during 1, 2, 3 phase of action potential and hence repolarization becomes faster and more intense. Then duration of repolarization as well as duration of action potential (APD) will be decreased. Hyperkalemia of 8 $\mathrm{mEq} / \mathrm{L}$ shifts intracellular negativity from $-90 \mathrm{mV}$ to -70 $\mathrm{mV}$ which depolarizes the membrane partially. Partial depolarization due to hyperkalemia inactivates the $\mathrm{Na}^{+}$ channels. Inactivation of $\mathrm{Na}^{+}$channels also prevents $\mathrm{Na}^{+}$ entry during $\mathrm{O}$ phase of depolarization of APD, which also decreases conduction velocity. Inactivation gates of $\mathrm{Na}^{+}$channels in the membrane close over the potential range - $75 \mathrm{mV}$ to $-55 \mathrm{mV}$. Decreased conduction velocity due to $\mathrm{K}^{+}$efflux and inactivation of $\mathrm{Na}^{+}$ channels, decreases pacemaker rates and pacemaker arrhythmogenesis. When initiation of phase 0 of depolarization is inhibited, automaticity and excitability both are inhibited. An increase in plasma potassium concentration can cause cardiac arrhythmia, and higher concentrations can lead to cardiac arrest.

In Purkinje fibers, action potential duration is highest and duration of 4th phase of action potential (slow diastolic depolarization) is lowest in comparison to other tissues like atrium and ventricle. Duration of diastolic interval (4th phase of action potential) is very important because in this phase inactivated $\mathrm{Na}^{+}$channels are converted in to resting $\mathrm{Na}^{+}$channels. Hyperkalemia, by partial depolarization, further reduces duration of 4th phase of action potential in Purkinje fibers then most of the inactivated $\mathrm{Na}^{+}$channels do not convert in to resting channels then they are not ready to open for $\mathrm{Na}^{+}$entry during depolarization. Due to less resting time between successive APD in comparison to other cardiac tissues, 
Purkinje fibers are highly sensitive for inhibitory action of hyperkalemia.

"Slow reduction (depolarization) of the resting potential, whether brought about by hyperkalemia, sodium - pump blockade or ischemic cell damage, results in depressed sodium currents during the upstroke of action potentials. Depolarization of the resting potential to level positive to - $55 \mathrm{mV}$ abolishes sodium currents, since all sodium channels are inactivated."11

\section{EFFECTS OF HYPOKALEMIA ON CARDIAC TISSUES}

Hypokalemia is defined when plasma concentration of potassium is less than $3.5 \mathrm{mEq} / \mathrm{L}$. If extra cellular concentration of $\mathrm{K}^{+}$is $3 \mathrm{mEq} / \mathrm{L}$ then resting potential will be

$$
\mathrm{K}_{\mathrm{EMF}}=-61 \log \frac{\mathrm{K} \text { inside concentration }}{\mathrm{K} \text { outside concentration }}=-61 \log \frac{142 \frac{\mathrm{mEq}}{\mathrm{L}}}{3 \frac{\mathrm{mEq}}{\mathrm{L}}}=-61 \log 47=-102.6 \mathrm{mV}
$$

$$
\log 47=1.60
$$

In hypokalemia of $3 \mathrm{mEq} / \mathrm{L}$ concentration, MRP is -102 $\mathrm{mV}$. Very slight leakage of $\mathrm{Na}$ from extra cellular site into intracellular site alters resting potential in hypokalemia minutely. In this hypokalemia, MRP is $102 \mathrm{mV}$. For neutralizing concentration gradient of $\mathrm{K}^{+}$, during resting condition of cell Nernst potential should be - $90 \mathrm{mV}$. But in hypokalemia, Nernst potential is - 102 $\mathrm{mV}$ which is greater than normal MRP. In hypokalemia electric gradient dominates over concentration gradient then electric gradient favours shifting of $\mathrm{K}^{+}$from extra cellular fluid in to intracellular fluid. $\mathrm{K}^{+}$will retain inside the cell. Electric gradient will oppose migration of $\mathrm{K}^{+}$ ions from intracellular compartment to intracellular compartment. Then reduced efflux of $\mathrm{K}^{+}$reduces $\mathrm{K}^{+}$ conductivity. If voltage difference is increased, as in hypokalemia then by Ohm's law, conductivity will be decreased. As we know by Ohm's law,

\section{Current $=$ Voltage difference $\mathrm{x}$ Conductivity}

Reduced $\mathrm{K}^{+}$efflux from leaky $\mathrm{K}$ channels (leaky $\mathrm{K}^{+}$ channels are always remain open) and sudden entrance of $\mathrm{Na}^{+}$during $\mathrm{O}$ phase of depolarization promote conduction velocity. Therefore conduction velocity is increased in hypokalemia. And by similar action slope of pacemaker potential is also increased.

Due to decreased $\mathrm{K}^{+}$conductance, $\mathrm{K}^{+}$efflux is decreased during 1, 2, 3 phase of action potential and hence repolarization becomes slower and less intense. Then duration of repolarization, as well as duration of action potential (APD) will be increased.

"The interval between depolarization of a pacemaker cell is sum of the duration of the action potential and the duration of the diastolic interval. The more important of the two, diastolic interval, is determined primarily by the slope of phase 4 depolarization (pacemaker potential). Acceleration of pacemaker discharge is often brought about by increased phase 4 depolarization slope, which can be caused by hypokalemia, $\beta$ adrenoreceptor stimulation, fiber stretch and by current of injury." 12 Hypokalemia increases slope of phase 4 of action potential due to reduction of $\mathrm{K}^{+}$efflux (reduced $\mathrm{K}^{+}$ conductance) which is responsible for increased pacemaker activity, increased early and delayed after depolarization (EAD, DAD) and increased ectopic activity.

Effect of hypokalemia and hyperkalemia on SA node is very less because in SA node $\mathrm{K}$ conductivity is already very low which can not be altered by altering $\mathrm{K}$ concentration in blood.

\section{EXPLANATION OF THE BASIC CARDIAC EFFECTS OF POTASSIUM WITHOUT CAUSING HYPERKALEMIA}

Extra cellular fluid potassium concentration is 4.2 $\mathrm{mEq} / \mathrm{L}$. Extra cellular fluid volume is $14 \mathrm{~L}$. Intracellular fluid potassium concentration is $142 \mathrm{mEq} / \mathrm{L}$ and total intracellular fluid volume is $28 \mathrm{~L}$. Total potassium in extra cellular compartments is $59 \mathrm{mEq}$ and in intracellular compartments is $3920 \mathrm{mEq}$. Normal intake of $\mathrm{K}^{+}$in diet is $100 \mathrm{mEq} /$ day and $\mathrm{K}^{+}$output by urine is 92 $\mathrm{mEq} /$ day and by faeces is $8 \mathrm{mEq} / \mathrm{day}$. Maintenance of potassium balance depends primarily on excretion by kidneys. Control of potassium distribution between the extra cellular and intracellular compartments also plays an important role in $\mathrm{K}$ homeostasis. When potassium is administered in slow infusion hyperkalemia is not developed but cardiac effects of hyperkalemia are produced, which can be explained as follow.

"If serum potassium increases of only a few tenth of a milliequivalent, stimulate pancreatic insulin secretion in to portal circulation in an attempt to prevent hyperkalemia from occuring." 13

"Insulin stimulates the acellular $\mathrm{Na}^{+}-\mathrm{K}^{+}$-ATPase pump to increase cellular potassium uptake in the liver, muscle, and adipose tissue"14 "Increased potassium intake also stimulates secretion of aldosterone, which increases cell potassium uptake." 15

There are many compensatory mechanisms which controls extra cellular $\mathrm{K}^{+}$concentration which seldom rising or falling more than $\pm 3 \mathrm{mEq} / \mathrm{L}$. 
"Often Potassium should not be given directly in to a vein or into the tubing of an intravenous infusion as this may cause sudden rise in serum $\mathrm{K}^{+}$level and death from cardiac arrest." 16 "Intravenous potassium is used in severe cases of hypokalemia or when patients are unable to tolerate oral therapy. The vehicle in which intravenous potassium is administered is important. Whenever possible, potassium should be mixed in saline containing solutions (e.g. $.9 \%$ or $.45 \% \mathrm{NaCl}$ ) and not dextrose containing solutions. Dextrose containing solutions stimulate insulin secretion, which causes further intracellular shifting of potassium. Generally, 10 to 20 $\mathrm{mEq}$ of potassium is diluted in $100 \mathrm{ml} .9 \% \mathrm{NaCl}$ for intravenous administration. These concentrations are generally safe when administered through a peripheral vein over 1 hour"17

Now this complexity of actions of $\mathrm{K}^{+}$administration, which does not cause hyperkalemia but produces cardiac effects of hyperkalemia, can be solved by following arguments. We are taking one example to explain it. e.g. if $\mathrm{K}^{+}$is administered in $126 \mathrm{mEq}$ dose in a slow drip then due to compensatory mechanisms. Extra cellular concentration of $\mathrm{K}^{+}$will rise slightly. Released insulin and aldosterone due to $\mathrm{K}^{+}$administration shift extra $\mathrm{K}^{+}$ ions in to intracellular compartments. If a large portion of $126 \mathrm{mEq} \mathrm{K}$, shifts inside the cell then intracellular $\mathrm{K}^{+}$ concentration will rise from $142 \mathrm{mEq} / \mathrm{L}$ to $146 \mathrm{mEq} / \mathrm{L}$ and extra cellular $\mathrm{K}^{+}$will rise slightly from $4.2 \mathrm{mEq} / \mathrm{L}$ to $5.2 \mathrm{mEq} / \mathrm{L}$. In the resting condition when MRP is -90 $\mathrm{mV}$, concentration gradient equalizes with the electrical gradient. Chemical gradient pushes $\mathrm{K}$ outside the cell while electrical gradient pushes $\mathrm{K}^{+}$inside the cell. When additional $\mathrm{K}^{+}, 126 \mathrm{mEq}$ is administered then it is distributed according to extra and intracellular volume. Extra cellular fluid volume is 14 liters. While intracellular fluid volume is 28 liter. Due to compensatory mechanisms, $\mathrm{K}^{+}$ion enters into the cell and increases intracellular concentration of $\mathrm{K}^{+}$from 142 $\mathrm{mEq} / \mathrm{L}$ to $146 \mathrm{mEq} / \mathrm{L}$ (112 $\mathrm{mEq}$ enters inside the cell) while remaining $14 \mathrm{mEq} \mathrm{K}$ retain outside the cell and increases extra cellular $\mathrm{K}$ from $4.2 \mathrm{mEq} / \mathrm{L}$ to $5.2 \mathrm{mEq} / \mathrm{L}$. We can imagine that only $14 \mathrm{mEq} \mathrm{K}^{+}$retains extra cellular, which increases extra cellular concentration of $\mathrm{K}^{+}$with $14 / 14=1 \mathrm{mEq} / \mathrm{L}$. Remaining $112 \mathrm{mEq} \mathrm{K}{ }^{+}$shifts intracellularily which increases intracellular concentration with $112 / 28=4 \mathrm{mEq} / \mathrm{L}$. Now revised MRP after administration of $126 \mathrm{mEq} \mathrm{K} \mathrm{K}^{+}$will be as followed by Nernst equation -

$$
\mathrm{K}_{\mathrm{EMF}}=-61 \log \frac{\mathrm{K} \text { inside }}{\mathrm{K} \text { outside }}=-61 \log \frac{146 \mathrm{mEq} / \mathrm{L}}{5.2 \mathrm{mEq} / \mathrm{L}}=-61 \log 28=-84 \mathrm{mV}
$$

After $\mathrm{K}^{+}$administration MRP will be $-84 \mathrm{mV}$ which is less than normal MRP but hyperkalemia is not developed due to compensatory mechanisms. MRP is also reduced in hyperkalemia and produces cardiac effect by increasing $\mathrm{K}$ conductivity. Therefore we can conclude that cardiac effects are same after $\mathrm{K}^{+}$administration irrespective of development of hyperkalemia due to increased $\mathrm{K}^{+}$conductivity.

If compensatory mechanisms are intact then hyperkalemia will not be developed after $\mathrm{K}^{+}$ administration, if potassium is administered in slow drip. If compensatory mechanisms fail then hyperkalemia will be produced after $\mathrm{K}^{+}$administration. In both the conditions cardiac effects will be the same which are -

1. Reduction in conduction velocity.

2. Reduced APD, and reduced ERP in atrium and ventricle. But propagation of impulses will be reduced due to extreme reduction of conduction velocity.

3. SA node is less sensitive to $\mathrm{K}^{+}$concentration because in SA node, $\mathrm{K}^{+}$conductivity is less which does not alter with alteration of $\mathrm{K}^{+}$concentration.

4. Reduction of MRP prolongs ERP of ectopic tissues because it inactivates $\mathrm{Na}$ channels due to partial depolarization which decrease slope of pacemaker potential.

\section{CONCLUSION}

It can be interpreted from the above discussion that understanding of effects of potassium on cardiac tissue requires sound knowledge of basic science and for a teacher requires a great deal of excellence to deliver such difficult topic. Since disturbance in potassium concentration is an emergency condition with detrimental effect on cardiac tissue, it's very important for medical students to understand this well in detail and hope this article will help them in doing so.

\section{Funding: No funding sources \\ Conflict of interest: None declared \\ Ethical approval: Not required}

\section{REFERENCES}

1. Drazen J.M. A Good Teacher. N Eng J Med. 2006;355:1374.

2. Hume J R, Grant AD. Agents used in Cardiac Arrhythmia. In: Katzung BG, editor. Basic and Clinical Pharmacology. $9^{\mathrm{th}}$ ed. Boston: McGraw Hill; 2004: 218.

3. Sharma HL, Sharma KK. Principles of Pharmacology. $1^{\text {st }}$ ed. Hyderabad: Paras Medical Publisher; 2007: 311.

4. Satoskar RS, Bhandarkar SD, Ainapure SS. Pharmacology and Pharmacotherapeutics. $18^{\text {th }}$ ed. Mumbai: Popular Prakashan; 2003: 376. 
5. Peterson LN, Levi M. Disorder of potassium metabolism. In Schrier RW, editor. Renal and electrolyte disorders. $6^{\text {th }}$ ed. Philadelphia: Lippincott; 2003: 171-215.

6. Lee CAB, Barrett CA, Ignatavicius DD. Fluids and Electrolytes: A practical Approach. $4^{\text {th }}$ ed. Philadelphia: FA Davis; 1996 : 57-71.

7. Brophy DF, Gehr TWB, Disorders of potassium and magnesium homeostasis. In : Dipiro JT, Talbert RL, Yee GC, Matzkee GR, editors. Pharmacotherapy. $6^{\text {th }}$ ed. New York: McGraw Hill; 2005: 967.

8. Alberts B, Bray D, Lewis J, Raff M, Roberts K, Watson JD. The cell. $3^{\text {rd }}$ ed. New York: Garland Publishing; 1994: 524.

9. Alberts B, Bray D, Lewis J, Raff M, Roberts K, Watson JD. The cell, $3^{\text {rd }}$ ed. New York: Garland Publishing; 1994: 525.

10. Guyton AC, Hall JE. Text Book of Medical Physiology. $10^{\text {th }}$ ed. Singapore: Harcourt Publisher; 2000: 52.

11. Hume J R, Grant AD. Agents used in Cardiac Arrhythmia. In: Katzung BG, editor. Basic and Clinical Pharmacology. $9^{\text {th }}$ ed. Boston: McGraw Hill; 2004: 220.
12. Hume $\mathrm{J}$ R, Grant AD. Agents used in Cardiac Arrhythmia. In: Katzung BG, editor. Basic and Clinical Pharmacology. $9^{\text {th }}$ ed. Boston: McGraw Hill; 2004: 221.

13. Brophy DF, Gehr TWB, Disorders of potassium and magnesium homeostasis. In : Dipiro JT, Talbert RL, Yee GC, Matzkee GR, editors. Pharmacotherapy. $6^{\text {th }}$ ed. New York: McGraw Hill; 2005: 968.

14. Sharma K, Cox M. Potassium Homeostasis. In Szerlip HM, Goldfarb S, editors. Workshops in Fluid and Electrolyte disorders. Newyork: Churchill Livingstone; 1993: 71-96.

15. Guyton AC, Hall JE. Text Book of Medical Physiology. $10^{\text {th }}$ ed. Singapore: Harcourt Publisher; 2000: 337.

16. Satoskar RS, Bhandarkar SD, Ainapure SS. Pharmacology and Pharmacotherapeutics. $18^{\text {th }}$ ed. Mumbai: Popular Prakashan; 2003: 517-518.

17. Brophy DF, Gehr TWB, Disorders of potassium and magnesium homeostasis. In : Dipiro JT, Talbert RL, Yee GC, Matzkee GR, editors. Pharmacotherapy. $6^{\text {th }}$ ed. New York: McGraw Hill; 2005: 971.

doi:10.5455/2319-2003.ijbcp20140234

Cite this article as: Arya RK, Sharma P, Jain DR.

Understanding of effects of potassium on cardiac tissue by medical students: a critical appraisal. Int J Basic Clin Pharmacol 2014;3:18-23. 